\title{
Perception of post-stroke patients on case management conducted by nurses*
}

\author{
Percepção de pessoas pós-Acidente Vascular Cerebral sobre o \\ gerenciamento de caso conduzido por enfermeiro \\ Percepción de personas que han sufrido un accidente cerebrovascular \\ sobre la gestión del caso conducida por un enfermero
}

How to cite this article:

Souza PB, Mantovani MF, Silva ATM, Paz VP. Perception of post-stroke patients on case management conducted by nurses. Rev Esc Enferm USP. 2021;55:e03703. doi: https://doi.org/10.1590/S1980-220X2019026703703

\section{Pollyanna Bahls de Souza ${ }^{1}$ \\ Maria de Fátima Mantovani ${ }^{1}$ \\ Ângela Taís Mattei da Silva² \\ Vanêssa Piccinin Paz ${ }^{3}$}

* Extracted from the thesis: "Gerenciamento de caso conduzido por enfermeiro para pessoas com Acidente Vascular Cerebral: estudo de métodos mistos”, Programa de Pós-Graduação em Enfermagem, Universidade Federal do Paraná, 2019.

1 Universidade Federal do Paraná, Programa de Pós-Graduação em Enfermagem, Curitiba, PR, Brazil.

2 Conselho Regional de Enfermagem, Curitiba, PR, Brazil.

3 Secretaria Municipal de Saúde, Cascavel, PR, Brazil.

\begin{abstract}
Objective: To identify the perception of post-stroke patients on the case management conducted by nurses. Method: Qualitative descriptive study with 13 post-stroke patients, followed-up with case management conducted by a nurse for six months, and interviewed at home one month after the end of the follow-up. The interviews were recorded, transcribed in full and analyzed with the help of a software. Results: Of the 13 participants, $57.14 \%$ were men and $50 \%$ were between 50 and 59 years. Content analysis resulted in three categories: "Self-management of care", which addressed changes in attitudes towards treatment, mainly due to concern of recurrence in a short period of time; "Sequelae and late repercussions of the stroke", which presents participants' difficulties after the event; and "Support received after a stroke", which emphasizes the actions and attitudes of the case manager nurse during the follow-up period. Conclusion: Case management was perceived by the participant as a health-promoting tool capable of increasing treatment adherence.
\end{abstract}

\section{DESCRIPTORS}

Stroke; Nursing Care; Case Management; Adult Health. 


\section{INTRODUCTION}

Cerebral Vascular Accidents (CVAs) or strokes are responsible for temporary or chronic disability of people affected, due to limitations in physical, psychological, and social capacity. One in four people who had a CVA die in the first year, while approximately 35\% have sequelae and need help with daily activities, which affects their professional reintegration ${ }^{(1)}$.

CVAs affected 33 million people around the world in 2010: around 16 million of these people had their first episode and about $30 \%$ were under 65 years old ${ }^{(2)}$. In Brazil, strokes are the main cause of hospitalizations, mortality, and disabilities, overcoming several other heart diseases and even cancer. This situation results in a considerable socioeconomic impact ${ }^{(3-4)}$.

A Brazilian study pointed out that the incidence of CVAs in Brazil was 108 cases per year for every 100 thousand inhabitants, with a $18 \%$ death rate in the first 30 days, $31 \%$ rate of deaths after one year, and a $15.9 \%$ recurrence rate ${ }^{(3)}$. The mortality rate in the first month after a recurrent stroke ranges from $23 \%$ to $41 \%$, with an increased risk for disability $(39 \% \text { to } 53 \%)^{(5)}$.

Systemic Arterial Hypertension (SAH), diabetes mellitus, and heart diseases are risk factors for CVAs, as well as behavioral factors, including overweight, physical inactivity, alcohol and tobacco consumption and use of oral contraceptives. These factors can accelerate the atherosclerosis process ${ }^{(6-7)}$.

The location of the stroke influences the onset of sequelae, depending on the duration of inadequate perfusion in brain tissue and the existence of collateral circulation. The most common changes associated with CVAs are sensory, psychological, cognitive, and motor disorders ${ }^{(8)}$.

The wide variety of neurological deficits left by a stroke reinforces the importance of this problem. There are numerous limitations associated with the disease, such as difficulty in locomotion, communication, feeding, vision, adherence to treatment, control of pre-existing diseases, among others. Therefore, the health care team, especially the nurse, has the role of advocating in favor of the patient, making it possible to plan care according to individual needs, contributing to their rehabilitation ${ }^{(6)}$.

Regarding the models of care for people with chronic diseases in Brazil, a model based on the Risk Pyramid Model, the Model for Attention to Chronic Conditions (MACC) was proposed for the Unified Health System (Sistema Único de Saude-SUS). This model presents actions according to the severity of the chronic condition and emphasizes the promotion of health to the population. It is structured according to self-care actions for the simplest conditions and health management for people who have an established disease. It also applies case management technology to people with complex health conditions ${ }^{(9)}$.

In this regard, case management can be defined as a process developed between the case manager and a person with a complex health condition (situations of frequent readmissions in health services, high-cost treatment, and need for high complexity resources). In cooperation with the social support network, this management improves the quality of life and the autonomy of the patient and their family.

Consequently, case management is a possibility of care to be used by nurses for people affected by CVAs, considering its beneficial results, such as reduction of hospitalizations, social admissions and adverse events ${ }^{(9)}$. Considering that CVAs are an acute complication of chronic illness, that care with a view to reducing recurrent episodes is adjuvant in clinical treatment, and that people affected need to work with nurses to self-manage their treatment, this study aimed to identify the perception of post-stroke patients about the case management conducted by the nurse.

\section{METHOD}

\section{TYPE OF STUDY}

This is a qualitative, descriptive study.

\section{SCEnARIO}

The study was carried out from March 2016 to July 2019, in a city in the central region of southern Paraná state, and is linked to the research "Case management for people with stroke conducted by nurses: a mixed methods study".

\section{Data collection}

The participants were 13 post-stroke patients who received follow-up care with case management conducted by a nurse for six months. Participants were recruited in two public philanthropic hospitals. The researchers made daily contact with the person responsible for the admission of stroke patients, whether a nurse or a physician. When informed about the hospitalization of a patient with a medical diagnosis of CVA, the researcher went to the hospital and applied the other inclusion criteria: having a previous diagnosis of $\mathrm{SAH}$, residing in the research city, being an adult between the ages of 18 and 64 and with a maximum score of four points in the Rankin Scale at the time of discharge. Those who intended to move out of the city in the months of data collection were excluded. After the acceptance to participate in the research, the researcher scheduled the first home visit for after the participant's hospital discharge.

Case management was carried out by the researcher and the activities that comprised the intervention were: telephone calls, home visits, nursing consultation with the establishment of goals. During follow-up, the patients received referrals for medical consultation and for consultation with other professionals (physical therapist, nutritionist and psychologist), referral/follow-up at the Basic Health Unit (Unidade Básica de Saúde - UBS), and guidelines on dietary changes, development of strategies to favor adherence to medication and non-medication therapy and to promote healthy lifestyle habits, such as weight reduction, physical activity and reduction of waist circumference, blood glucose and blood pressure.

The interview was conducted alone with participants in their residence within one month after the end of the 
follow-up, according to their availability. The interviews were recorded and transcribed in full and had a duration of 15 minutes. Changes and/or corrections made to the text were subsequently read by participants, according to the Consolidated criteria for reporting qualitative research $(\mathrm{COREQ})^{(10)}$.

\section{Data ANALYSIS AND TREATMENT}

The transcriptions were analyzed with the help of the Interface de R pour les Analyses Multidimensionnelles de Textes et de Questionnaires (IRAMUTEQ 0.6-alpha ${ }^{\circledR}$ ) software. This is a free software that allows the analysis of texts from interviews and other discursive documents ${ }^{(11)}$.

The corpus built consisted of the insertion of texts in the OpenOffice.org software, in a single file saved in text. txt format and separated by command lines according to the variables, for recognition of the IRAMUTEQ 0.6-alpha $3^{\circledR}$ software. Based on the initial corpus, the text segments that make up each class are separated and called Initial Context Units (ICU). Iramuteq allows several types of analysis and the one used in this study was the Descending Hierarchical Classification (DHC) ${ }^{(11-12)}$.

The data were processed, grouped and classified according to the occurrence of the words. The DHC allowed the presentation of a dendrogram of the classes, demonstrating the association between the classes ${ }^{(12)}$. In this research, classes with similar ICUs were grouped into categories. The names of the participants were replaced by the letter $\mathrm{P}$.

\section{ETHICAL ASPECTS}

The research was approved by the Ethics Committee of the Universidade Estadual do Centro-Oeste, under
Opinion 3.002.936 of 2018. Respecting the principles of Resolution No. 466/2012, all participants read and had neurological and physical conditions to sign the Informed Consent Form. After the end of the research, the participants were referred to the Health Units to continue their monitoring.

\section{RESULTS}

Of the 13 people who participated in the research, $57.14 \%$ were men, $92.85 \%$ were married/in a stable relationship, 50\% were between 50 and 59 years old, followed by $28.57 \%$ who were between 60 and 64 years old, $78.57 \%$ had incomplete elementary education, $35.71 \%$ had household activities as occupation and $50 \%$ had an income of up to two minimum wages. The Rankin Scale classification showed that four participants were in class 1 (no significant disabilities), five in class 2 (mild disability), one participant in class 3 (moderate disability) and three in class 4 (moderately severe disability).

When importing the corpus to the Iramuteq software, the processing occurred in 12 seconds. A total of 132 text segments were used, out of 157 that were classified, showing a coverage of $84.08 \%$.

For the presentation of the dendrogram, the corpus was divided into two subcorpora, the first being formed by classes 5 and 6 , which obtained, respectively, $22.7 \%$ and $12.1 \%$ of the ICUs. The second subcorpus was formed by classes 3 and 4, with $14.4 \%$ and $18.9 \%$ of the total ICUs, respectively, and by classes 1 and 2, with $18.9 \%$ and $12.9 \%$ of the total ICUs. At the bottom of the classes, there is a list of words derived from the chi-square test (Figure 1).

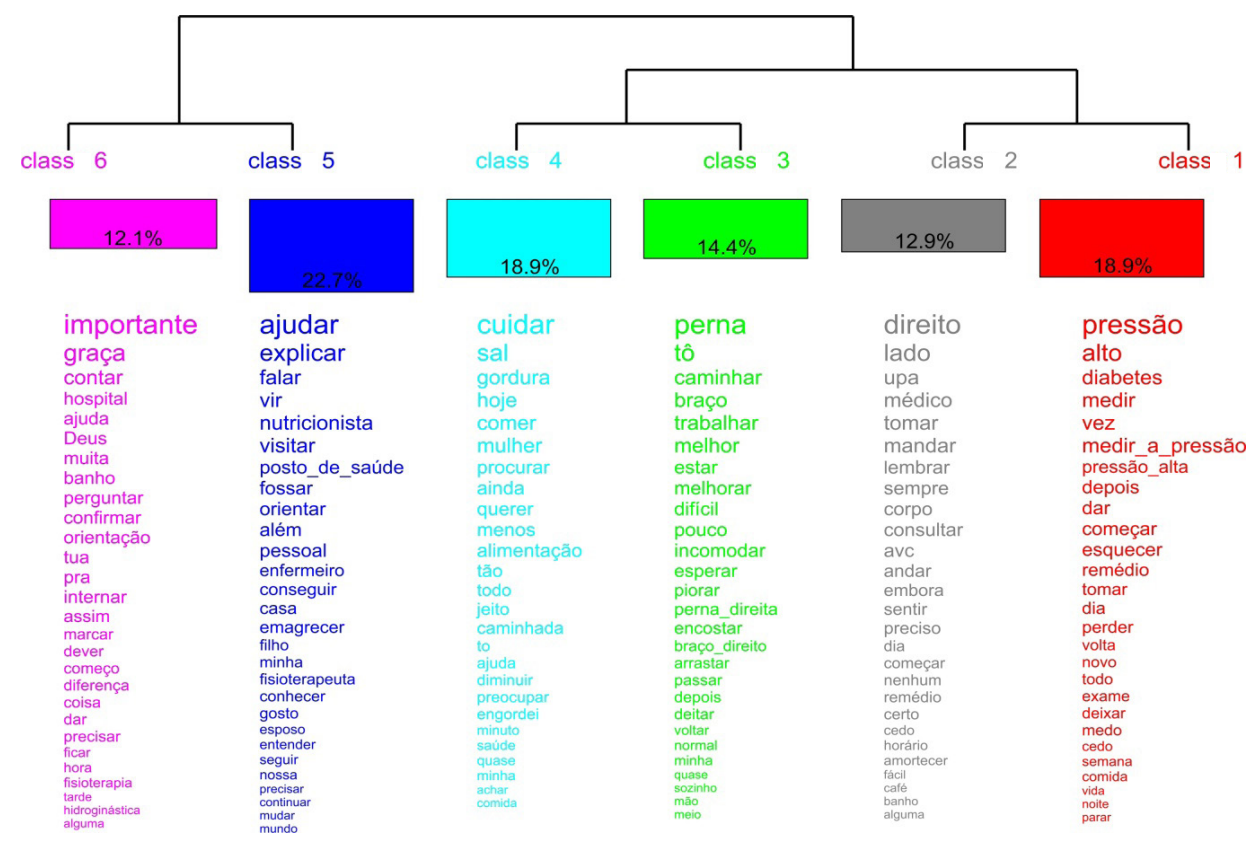

Figure 1 - Representation of the dendrogram with the percentage frequency of the ICUs by class and chi-square values $(\chi 2)$ of the words, generated by IRAMUTEQ. 
The first category, "Self-management of care", was composed of classes 1 and 2 and referred to changes in attitudes towards medication and non-medication therapy, explained by the concern of having a new stroke.

The following reports refer to changes in attitudes related to non-medication aspects:

(...) I take care of myself more nowadays than I used to, I'm on a diet, I go for walks (P5).

(...) I keep checking my blood pressure every day. Before, I did not do any physical activity. Now, I exercise on the walking simulator every day. I started doing 20 minutes and now I walk for 1 hour (P3).

(...) I drank 3 cans of beer this week. Before, I would drink 3 packs. The cigarettes are difficult, I still smoke 2 packs a day, but I used to smoke 4! Nowadays, we no longer use seasoning in food (P10).

(...) I take care of myself more today, but I still think it is too little. Today, I worry more about health because of the fear of recurrence, because I know it can happen! (P6).

The reports of $\mathrm{P} 7$ and $\mathrm{P} 9$ represent the self-management of care related to adherence to drug treatment:

(...) I take the medicine correctly. I don't forget it and I don't take more than the doctor prescribed. I want to be more careful so I don't have another stroke like that. Can you imagine being in a bed without being able to walk?! (P7).

(...) the first thing I do early in the morning is to measure blood pressure, blood glucose and take my medications. I never forget it! (P9).

Classes 3 and 4, corresponding to the second category, presented speeches related to the difficulties of post-stroke participants, called "Sequelae and late repercussions of the stroke".

(...) I can't walk alone properly... I always have someone by my side to support me! (P11).

(...) after I came home, it took me a while to get on track. Today I am not 100\% ready to write, but I have improved (P9).

(...) I needed a lot of help in the beginning, to bathe, walk and eat. Today, I bathe alone, walk alone, but I still get nervous and sad because I can't do things the way I did before (P2).

Classes 5 and 6 correspond to the third category, called "Support received after a stroke", which shows the support provided by the case manager during the research intervention. The need for support is represented in the next statement:

(...) everyone in my family understood better what I can eat. They are always here; everyone helps... even my wife who also has high blood pressure managed to lose weight! (P12).

Below, some reports demonstrate the participants' perception of the case management received and the importance of the case manager for their recovery:

(...) thanks to your help, I managed to get the health clinic to schedule my physical therapies and even water aerobics, because not everyone can get it $(\mathrm{P} 8)$.
(...) you explained to me and to my family how to deal with the difficulties that come with the stroke. You talked to the staff at the basic health unit and that's why they came to visit me after discharge from the hospital, which was the most difficult moment! (P10).

(...) it was a very important support for me, it made a lot of difference. How many patients went through this and did not have the same guidelines as I did? It really is a public health problem that, thanks God, was different to me (P6).

\section{DISCUSSION}

There was a predominance of males and patients aged over 50 years. This result is in line with a study carried out at a University hospital in São Paulo, in which the mean age of patients admitted to the neurology service was 53.4 years and $63.2 \%$ of patients were male ${ }^{(7)}$. Regarding education and income, the results were similar to a study conducted in Recife, where participants had low education and low income ${ }^{(13)}$.

In the first category, "Self-management of care", participants emphasized issues about adaptation, changes in lifestyle and medication adherence, which were supported by the case manager's work. This fact corroborates the definition of self-management of care, which is the ability of people to manage the symptoms and changes resulting from illness, either individually or with the support of their families and, in this case, with the intervention of the case manager ${ }^{(14)}$.

Due to the repercussions of chronic diseases on morbidity, mortality, and health care costs, self-management of care helps controlling the disease, as the patients start to contribute to self-care, even with their limitations ${ }^{(14)}$.

Participants also reported having included some actions, such as blood pressure measurement, in their self-care routine. These actions taken to care for chronic diseases are important to reduce the damage caused by this condition. Thus, identifying signs and symptoms, handling equipment and testing devices, and changing lifestyle are proactive actions for disease control ${ }^{(15)}$.

Participants performed self-management actions to prevent risk factors for stroke complications. In this sense, the actions taken were the search for a healthy diet and physical activities. It is worth noting that this set of attitudes towards a favorable lifestyle to control SAH should also be adopted in order to prevent stroke, in addition to stress control, reducing alcohol and tobacco consumption and adhering to drug treatment ${ }^{(16)}$.

In the speech by $\mathrm{P} 10$ it is possible to notice that, despite the reduction in the daily alcohol intake and cigarette consumption, there is a difficulty to leave these substances. It was verified that, despite the existing problems in lifestyle changes, self-management appears in the fact that the participant identifies the need for health, through collaborative attitudes to meet the guidelines of the case manager ${ }^{(14)}$.

It was also found that participants were concerned about adhering to drug treatment, following the correct dosages and prescription times, as this action is an important component for SAH management and prevention of cardiovascular events. In this sense, the monitoring of patients and family 
members involved in the care process by the health team is indicated to increase adherence and treatment success ${ }^{(16)}$.

A randomized study in which the nurse followed-up patients to assess the prevention of cardiovascular diseases and lifestyle changes found results like those of this study. The actions were associated with changing healthy lifestyle behaviors (healthy eating, physical activity) and increasing medication adherence. In this sense, the nurse's action in case management is assessed as positive, particularly in relation to people with SAH and especially when it comes to the effect of the guidelines on lifestyle changes and adherence to treatment ${ }^{(17)}$.

A study developed in the state of Ceará with 193 people registered in the Clinical Management System for Arterial Hypertension and Diabetes Mellitus in Primary Care (SIS$H I P E R D I A)$ found that stroke was a warning sign, that generated changes in people's behavior in relation to adherence to drug therapy for $\mathrm{SAH}^{(18)}$. This fact corroborates the reports of the participants of this research, as the participants, with the assistance of the case manager, showed concern about adhering to drug treatment and reducing the risk of new complications.

The second category, "Sequelae and late repercussions of the stroke" shows that participants often had difficulty walking due to the limitations caused by the stroke. Walking independence is achieved when postural balance improves, but this balance is affected in post-stroke people, as a result of cognitive impairment and weight shift to the unaffected body part, which makes it difficult to perform daily activities. Thus, motor impairment has a strong correlation with impaired mobility and balance, which influence the amount of support that the post-stroke patient needs in order to walk ${ }^{(19)}$.

In the post-stroke period, the hemibody that is affected by the disease is in a state of flaccidity and insufficient muscle tone, which makes it difficult to start movement. Thus, functional disability can be considered one of the most important sequelae of strokes along with reduced cognitive function, which negatively influences long-term survival and recovery ${ }^{(20)}$.

Post-stroke people demonstrate muscle weakness and loss of dexterity, which affects their walking. Although some locomotion ability is recovered, a reduction in speed, length and gait can often occur. This condition, when associated with fear of falling and lack of confidence to walk, can limit the post-stroke person's participation in the community. This is why walking rehabilitation is important for recovering the individual's social participation ${ }^{(21)}$. In this research, the participant's referral to physical therapy was essential for strengthening the muscles, exercising balance, among other important aspects for rehabilitation. The reports of the participants of this research addressed the difficulties to walk and the need for support in carrying out activities of daily living, but there was no reference to the reasons for this limitation, whether due to fear of falling or lack of balance.

It is also possible to observe the impact of the deficit in physical, sensory and cognitive functioning on the performance of daily activities, as the patient needs to depend on other people. This can influence the ability to make decisions about what, when and how to perform a certain activity, interfering in autonomy and, consequently, causing negative feelings, such as anguish and sadness. In this situation, caregivers should seek to promote the autonomy of these people, in order to promote their individuality ${ }^{(3)}$.

Sadness and anxiety can appear after a stroke, due to the dependence on family or caregivers to perform daily activities, which were previously performed individually, as shown by the speech of participant P2. In a Canadian study carried out with post-stroke patients, the feeling of anxiety is often presented by patients, along with depression, which can negatively affect the social reintegration of the individual due to physical limitations and acceptance ${ }^{(22-23)}$.

"Support received after a stroke" is the third category, which demonstrates the relevance of significant people to the recovery of individuals. These people can be family members, partners, neighbors, friends or health professionals who have a positive relationship with the patient and offer help when needed. Often, the support for the changes required to achieve the goals established by the participant and the case manager, is given by the family members, who provide the motivation and the help to adapt daily activities. Thus, the rehabilitation process must address both patients and caregivers, since the consequences of the stroke affect everyone $^{(24)}$. Results from a Scottish study showed that the treatment of post-stroke patients was less difficult when it was shared with family and friends, who provide emotional support and assistance in daily living activities, increasing the patient's security to make decisions ${ }^{(25)}$.

The reports of the participants also refer to the lack of visits and support by the health team, especially of the team that was a reference for their monitoring. A study carried out with post-stroke people reveals that, at that moment, the patient needs to be oriented on their health, on how to avoid a new episode and on the best way to manage the situation. This reinforces the impact and the importance of the health team when monitoring patients who survived a stroke, especially for providing training on risk factors and the trajectory of recovery ${ }^{(26)}$.

The study carried out in Scotland also addressed the fact that, according to the participants' reports, there was poor communication with the health team that was monitoring the patient, showing an unsatisfactory primary care assistance. Another aspect identified was the participants' interest in knowing and updating themselves on the course of their stroke and on its control, treatment, recovery, among others ${ }^{(25)}$. Another benefit perceived by the research participants was the positive impact of the case management developed by the nurse throughout the recovery process, through individualized and interdisciplinary actions. Changing life habits requires an action plan that is developed according to the individual's level of understanding, which reduces their resistance to treatment and increases the possibility of setting strategies and goals to change habits according to the necessity, adapting when and how it is necessary ${ }^{(4,9)}$.

Among the benefits recognized by the participants regarding case management, there is the bond created between the post-stroke patient and the case manager nurse, evidenced by the statements that express trust between them. 
The trust developed over time allows the development of effective health practices, through the exchange of knowledge, experiences and the identification of important situations. This condition reinforces that adhering to the proposed care is of paramount importance for recovery and better health conditions ${ }^{(27)}$.

Another benefit of case management observed in the speeches was the fact that the patients feel more informed and, with this, feel more responsible for their recovery and care process. In this regard, a bibliographic review identified the importance of the case manager being a professional nurse, as they are the main reference for the patients and their families, mainly when it comes to health education to promote healthy habits and prevent diseases or complications ${ }^{(28)}$.

The importance and benefits of case management conducted by nurses are reinforced throughout the statements, as the participants identified the positive points of this type of care, stating that all post-stroke individuals should receive this type of monitoring.

A limitation of this study was the low number of participants and institutions. Furthermore, evaluations of case management activities did not take place during the process, occurring only 30 days after the end of the intervention.

\section{CONCLUSION}

The management interventions proposed in this study allowed to identify that this care model can be used by nurses for post-stroke patients, as it enables the establishment of a bond and the advocacy in favor of the patient. In addition, this care model assists in health promotion and in the prevention of complications associated with chronic diseases and, consequently, promotes the visibility of nurses in the treatment of chronic diseases.

\section{RESUMO}

Objetivo: Identificar a percepção de pessoas pós-Acidente Vascular Cerebral acerca do gerenciamento de caso conduzido pelo enfermeiro. Método: Pesquisa qualitativa descritiva, com 13 participantes pós-Acidente Vascular Cerebral, acompanhados pelo gerenciamento de caso conduzido por enfermeiro durante seis meses e entrevistados em seus domicílios um mês após do término do acompanhamento. As entrevistas foram gravadas, transcritas na íntegra e analisadas com auxílio de software. Resultados: Dos 13 participantes, 57,14\% eram homens, $50 \%$ com idade variando de 50 a 59 anos. A análise do conteúdo resultou em três categorias: "Autogestão do cuidado", referente às modificações de atitudes em relação ao tratamento, devido principalmente ao medo de recidiva em curto período de tempo; "Sequelas e repercussões tardias do Acidente Vascular Cerebral", que apresenta as dificuldades dos participantes após o evento; e "Apoio recebido pós-Acidente Vascular Cerebral”, que enfatiza as ações e atitudes do enfermeiro gerente de caso no período de acompanhamento. Conclusão: $\mathrm{O}$ gerenciamento de caso foi percebido pelo participante como uma ferramenta promotora de saúde e capaz de aumentar a adesão ao tratamento.

\section{DESCRITORES}

Acidente Vascular Cerebral; Cuidados de Enfermagem; Administração de Caso; Saúde do Adulto.

\section{RESUMEN}

Objetivo: Identificar la percepción de personas que han sufrido un Accidente Cerebrovascular sobre la gestión del caso realizada por un enfermero. Método: Se trata de una investigación cualitativa descriptiva, llevada a cabo entre 13 participantes que sufrieron un Accidente Cerebrovascular, cuyo seguimiento fue gestionado por un enfermero durante seis meses y que fueron entrevistados en sus domicilios un mes después de haberse terminado el seguimiento. Las entrevistas se grabaron y se transcribieron en su totalidad y se analizaron con la ayuda de programas informáticos Resultados: De los 13 participantes, el 57,14\% era del sexo masculino y el 50\% tenía una edad comprendida entre los 50 y los 59 años. El análisis del contenido dio como resultado tres categorías: "Autogestión del cuidado", que se refiere a los cambios de actitud hacia el tratamiento, principalmente por el miedo a una recidiva en un período corto; la segunda trata de las "Secuelas y repercusiones tardías del Accidente Cerebrovascular", que presenta las dificultades de los participantes después del hecho, y la tercera se refiere al "Apoyo recibido después del Ictus", que hace hincapié en las acciones y actitudes del enfermero gestor del caso durante el período de seguimiento. Conclusión: La gestión del caso fue percibida por el participante como una herramienta de promoción de la salud, capaz de aumentar la adhesión al tratamiento.

\section{DESCRIPTORES}

Accidente Cerebrovascular; Atención de Enfermería; Manejo de Caso; Salud del Adulto.

\section{REFERENCES}

1. Morais HCC, Gonzaga NC, Aquino PS, Araujo TL. Strategies for self-management support by patients with stroke: integrative review. Rev Esc Enferm USP. 2015;49(1):136-43. doi: http://dx.doi.org/10.1590/S0080-623420150000100018

2. American Heart Association. Heart disease and stroke statistics: 2015 update. A report from the American Heart Association. Circulation, 131:29-322. doi: https://doi.org/10.1161/CIR.0000000000000152

3. Reis RD, Pereira EC, Pereira MIM, Soane AMNC, Silva JV. Significados, para os familiares, de conviver com um idoso com sequelas de Acidente Vascular Cerebreal (AVC). Interface (Botucatu). 2017;21(62):641-50. doi: http://dx.doi.org/10.1590/1807-57622016.0206

4. Perry JJ, Losier JH, Stiell IG, Sharma M, Abdulaziz K. National survey of emergency physicians for impact ischemic attack (TIA) risk stratification consensus and appropriate treatment for given level of risk. J Stroke Cerebrovasc Dis. 2016;25(6):1517-23. doi: https://doi. org/10.1017/cem.2015.57

5. Bailey RR. Lifestyle modification for secondary stroke prevention. Am J Lifestyle Med. 2018; 12(2):140-7. doi: https://doi. org/10.1177/1559827616633683

6. Nunes DLS, Fontes WS, Lima MA. Cuidado de enfermagem ao paciente vítima de acidente vascular encefálico. Rev Bras Ci Saúde. 2017;21(1):87-96. doi: https://doi.org/10.4034/RBCS.2017.21.01.11

7. Rodrigues M, Santana L, Galvão I. Fatores de risco modificáveis e não modificáveis do AVC isquêmico: uma abordagem descritiva. Rev Med (São Paulo). 2017;96(3):187-92. doi: 10.11606/issn.1679-9836.v96i3p187-192 
8. Cavalcante TF, Moreira RP, Guedes NG, Araujo TL, Lopes MVO, Damasceno MMC, et al. Nursing interventions for stroke patients: an integrative literature review. Rev Esc Enferm USP. 2011;45(6):1495-500. doi: http://dx.doi.org/10.1590/S0080-62342011000600031

9. Mendes EV. O cuidado das condições crônicas na atenção primária à saúde: o imperativo da consolidação da estratégia da saúde da família. Brasília: OPAS; 2012.

10. Tong A, Sainsbury P, Craig J, Consolidated criteria for reporting qualitative research (COREQ): a 32-item checklist for interviews and focus groups. Int J Qual Health Care. 2007; 19(6):349-57. doi: https://doi.org/10.1093/intqhc/mzm042

11. Camargo BV, Justo AM. IRAMUTEQ: um software gratuito para análise de dados textuais. Temas Psicol. 2013;21(2):513-8. doi: http:// dx.doi.org/10.9788/TP2013.2-16

12. Souza MAR, Wall ML, Thuler ACMC, Lowen IMV, Peres AM. The use of IRAMUTEQ software for data analysis in qualitative research. Rev Esc Enferm USP. 2018;52:e03353. doi: http://dx.doi.org/10.1590/s1980-220x2017015003353

13. Melo SPSC, Cesse EAP, Lira PIC, Rissin A, Cruz RSBLC, Batista Filho M. Doenças crônicas não transmissíveis e fatores associados em adultos numa área urbana de pobreza do nordeste brasileiro. Ciênc Saúde Coletiva. 2019;24(8):3159-68. doi: https://doi.org/10.1590/141381232018248.30742017

14. Balduino AFA, Mantovani MF, Lacerda MR, Meier MJ. Análise conceitual de autogestão do indivíduo hipertenso. Rev Gaúcha Enferm. 2013;34(4):37-44. doi: http://dx.doi.org/10.1590/S1983-14472013000400005

15. Galvão MTRLS, Janeiro JMSV. O autocuidado em enfermagem: autogestão, automonitorização e gestão sintomática como conceitos relacionados. Rev Min Enferm. 2013;17(1):231-5. doi: http://www.dx.doi.org/10.5935/1415-2762.20130019

16. Malachias MVB, Póvoa RMS, Nogueira AR, Souza D, Costa LS, Magalhães ME. $7^{a}$ Diretriz Brasileira de Hipertensão Arterial: capítulo 3 - avaliação clínica complementar. Arq Bras Cardiol. 2016; 107(3 Supl.3):14-7.doi: http://dx.doi.org/10.5935/abc.20160153

17. Ozpancar N, Pakyuz SC, Topcu B. Hypertension management: what is the role of case management? Rev Esc Enferm USP. $2017 ; 51: e 03291$. doi: http://dx.doi.org/10.1590/S1980-220X2017016903291

18. Lima DBS, Moreira TMM, Borges JWP, Rodrigues MTP. Association between treatment compliance and different types of cardiovascular complications in arterial hypertension patients. Texto Contexto Enferm. 2016;25(3):e0560015. doi: http://dx.doi.org/10.1590/010407072016000560015

19. Medeiros CSP, Fernandes SGG, Souza DE, Guedes DT, Cacho EWA, Cacho RO. Comprometimento motor e risco de quedas em pacientes pós-acidente vascular encefálico. Rev Bras Ci Mov [Internet]. 2019 [citado 2019 ago. 19];27(1):42-9. https://portalrevistas.ucb.br/index. $\mathrm{php/RBCM/article/view/7940}$

20. Miranda MR, Bueno GCR, Ribeiro LC, Matos JFS, Fonseca CF. Benefícios da hidroterapia em pacientes após-acidente vascular cerebral (AVC). Rev Inic Cient Ext [Internet]. 2018 [citado 2019 ago. 19];1(n.esp.5):465-71. Disponível em: https://revistasfacesa.senaaires.com. br/index.php/iniciacao-cientifica/article/view/121/78

21. Nascimento L, Ada L, Rocha G, Salmela LT. Perceptions of individuals with stroke regarding the use of a cane forwalking: a qualitative study. J Bodyw Mov Ther. 2019;23:166e170. doi: https://doi.org/10.1016/j.jbmt.2018.02.001

22. Barcley R, Ripat J, Mayo N. Factors describing community ambulation after stroke: a mixed-methods study. Clin Rehabil. 2015;29(5):50921. doi: https://doi.org/10.1177/0269215514546769

23. Reis C, Faro A. Repercussões psicológicas após um acidente vascular cerebral (AVC): uma revisão de literatura. Psic Saúde Doenças. 2019; 20(1):16-32. doi: http://dx.doi.org/10.15309/19psd200102

24. Sorensen SL, Pedersen SKS, Pallesen H. Social psychological mechanisms and processes in a novel, health professional-led, selfmanagement intervention for older stroke individuals: a synthesis and phenomenological study. BMC Health Serv Res. 2019;19:320. doi: https://doi.org/10.1186/s12913-019-4150-x

25. Gallacher KI, May CR, Langhorne P, Mair FSM. A conceptual model of treatment burden and patient capacity in stroke. BMC Fam Pract. 2018; 19:9. doi: https://doi.org/10.1186/s12875-017-0691-4

26. Pearce G, Pinnock H, Epiphaniou E, Parke HL, Heavey E, Griffiths CJ, et al. Experiences of self-management support following a stroke: a meta-review of qualitative systematic reviews. PLoS One. 2015;10(12):e0141803. doi: https://doi.org/10.1371/journal.pone.0141803

27. Barroso VG, Mattos CM. Sentimento de pertencimento na constituição do vínculo em uma autogestão de saúde suplementar. Ciênc Cuid Saúde. 2016;15(4):616-23. doi: http://dx.doi.org/10.4025/cienccuidsaude.v15i4.33385

28. Ulbrich EM, Mattei AT, Mantovani MF, Madureira AB, Kalinke LP. Care models for people with chronic diseases: integrative review. Invest Educ Enferm. 2017;35(1):8-16. doi: http://dx.doi.org/10.17533/udea.iee.v35n1a02 